\title{
Effects of black locust and black pine on extremely degraded sites 60 years after afforestation - a case study of the Grdelica Gorge (southeastern Serbia)
}

\author{
Sara Lukić ${ }^{(1)}$, Damjan Pantić(1), \\ Snežana Belanović Simić ${ }^{(1)}$, \\ Dragan Borota ${ }^{(1)}$, Bojan Tubić ${ }^{(2)}$, \\ Matilda Djukić (1), Danijela \\ Djunisijević-Bojović ${ }^{(1)}$
}

The selection of tree species can affect the success of afforestation in the rehabilitation of degraded forest sites and forest restoration. In general, black locust (Robinia pseudoacacia L.) and black pine (Pinus nigra Arnold.) represent the most commonly used species in the afforestation of soils that have been degraded by erosion. As far as the extent of the ameliorative effects of black locust and black pine are concerned, it was found that they may play an important role in the selection of species for the afforestation of extremely degraded sites. This study is aimed at determining the potential of black locust and black pine to affect several soil properties, erosion control and $C$ stock, thus creating favourable site conditions for the restoration of previous forest vegetation. This research was conducted in the Grdelica Gorge in south east Serbia, where eight sample plots with an average size of 0.47 ha were established 60 years ago on terrain afforested with black locust and black pine. In each sample plot, we measured the diameter at breast height of all black locust and black pine trees, and the height of 10 black locust and 10 black pine trees in each diameter class. In addition, samples of mineral soil (from depths of $0-5,5-10$ and $10-20 \mathrm{~cm}$ ) were taken at 4 randomly selected soil profiles in each sample plot, and 8 samples of litter $(30 \times 30 \mathrm{~cm})$ were also collected. Additionally, laboratory analyses of the physical and chemical properties of the soil and litter were performed in 2 replicates. The obtained results showed that: (1) at the $0-5 \mathrm{~cm}$ depth, there was no statistically significant difference in the reaction of the soil solution, although a significant difference in the reaction of the soil solution between the soils under the two species was observed at soil depths greater than $5 \mathrm{~cm}$; (2) there was a significantly higher $\mathrm{N}$ content under black locust in the $0-5 \mathrm{~cm}$ soil layer; $(3)$ the reduction of soil loss under black locust is statistically significant in all observation periods; (4) black pine is more efficient in $\mathrm{C}$ storage. Our results demonstrate that black locust has the potential to improve soil properties and reduce soil loss caused by erosion, while its favourable impact does not decrease over time, making it more suitable for afforestation on degraded land in the examined area.

Keywords: Afforestation, Black Locust, Black Pine, Soil Properties, Soil Losses, Carbon Stock

land does not usually allow for natural forest regeneration (Barčić et al. 2006). Under the harsh conditions of these sites, reforestation is an instrument used to rehabilitate degraded forest sites and restore forests. In addition to preventing erosion
(1) University of Belgrade, Faculty of Forestry, Kneza Višeslava 1, 11030 Belgrade (Serbia); (2) PE “Vojvodinašume“, Preradovićeva 2, 21131, Petrovaradin (Serbia)

@ Sara Lukić (sara.lukic@sfb.bg.ac.rs)

Received: Nov 24, 2014 - Accepted: May 01, 2015

Citation: Lukić S, Pantić D, Belanović Simić S, Borota D, Tubić B, Djukić M, DjunisijevićBojović D (2015). Effects of black locust and black pine on extremely degraded sites 60 years after afforestation - a case study of the Grdelica Gorge (southeastern Serbia). iForest 9: 235243. - doi: 10.3832/ifor1512-008 [online 2015-08-22]

Communicated by: Tamir Klein and rapid surface runoff (Djorović et al. 2003, Whisenant 2005, Chirino et al. 2006, Blanco-Canqui \& Lal 2008), afforestation is used to provide other beneficial effects on the environment, including the improvement of microclimatic conditions in degraded sites, boosting of the conditions which allow for an increase in biodiversity (Wenhua 2004, El-Keblawy \& Ksiksi 2005) and carbon sequestration (Richter et al. 1999, Lal et al. 2003, Wang \& Madley 2004, Niu \& Duiker 2006). Moreover, the economic effect of afforestation on degraded lands is not negligible (Djorović et al. 2003), and among its other benefits this represents an important ecosystem service.

The selection of tree species can affect the type and intensity of the afforestation effects. In fact, different species selected for afforestation produce a range of different impacts on floristic diversity. Interestingly, previous research has shown that 


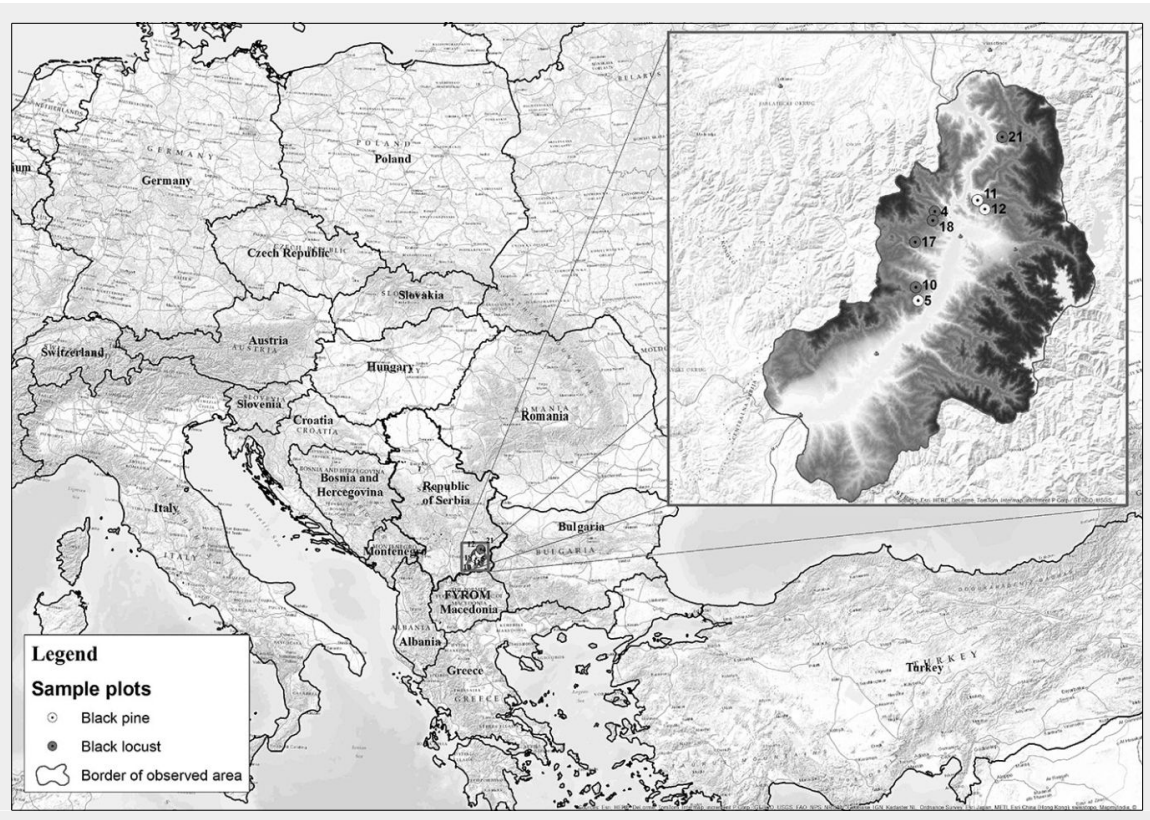

Fig. 1 - The study area of Grdelica Gorge, SE Serbia.

afforestation using different pine species (Pinus sp.) can have a negative impact on floristic diversity, species composition and the prospect of progressive succession (Andrés \& Ojeda 2002, Van Wesenbeeck et al. 2003, McNeely 2005, Barčić et al. 2006). However, a number of other ameliorative effects of afforestation with these species, such as erosion control (Cao et al. 2007), the improvement of certain soil properties such as organic matter content, $\mathrm{N}$ content, $\mathrm{C} / \mathrm{N}$ ratio, readily available $\mathrm{P}$ and $\mathrm{K}$ (Panagopoulos \& Hatzistathis 1995, Qiu et al. 2010) as well as atmospheric carbon sequestration in biomass and soil (Richter et al. 1999, Ouimet et al. 2007) should not be overlooked.

Cao et al. (2007) presented the results of the improvement in soil nutrient conditions, particularly in total and available $\mathrm{N}$ and organic matter, 10 years after afforestation, reporting that shallow-rooted species, such as black locust, are more suitable for the afforestation of degraded and erodible soils. Regarding the afforestation of lignite spoils with black locust and black pine, Panagopoulos \& Hatzistathis (1995) reported a larger amount of organic matter and a higher $\mathrm{N}$ content in the afforested soils compared to naturally revegetated soils. In fact, 14 years after afforestation, $\mathrm{N}$ content was $15 \%$ higher under black locust than under black pine. Research of the vegetation restoration effects on severely eroded barren land (Zhang et al. 2004) showed 4 to 6 times higher organic soil matter and total $\mathrm{N}$ in the afforested soils 12 years after vegetation restoration. Qiu et al. (2010) reported significantly increased $C$ and $\mathrm{N}$ contents in the surface soils under black locust compared to grassland, which increased the difference in soil organic $C$ and total $\mathrm{N}$ between the surface and deeper soils.
In this study, it was hypothesized that black locust and black pine can mitigate soil degradation in extreme site conditions. In particular, the investigation was aimed at determining the impact of black locust and black pine on certain soil properties, erosion control and C stock, as well as their potential to create favorable site conditions for the restoration of forest vegetation on degraded land.

\section{Materials and methods}

\section{Study area}

The area of the Grdelica Gorge extends between $42^{\circ} 22^{\prime}$ and $42^{\circ} 55^{\prime} \mathrm{N}$ latitude and between $21^{\circ} 19^{\prime}$ and $20^{\circ} 00^{\prime} \mathrm{E}$ longitude, on an area of $1784.34 \mathrm{~km}^{2}$ (Fig. 1). This area is characterized by a well developed hydrographic network consisting of 137 streams, with a total catchment area of $1700.33 \mathrm{~km}^{2}$. A combination of pronounced altitudinal differences over short distances and dissected relief with steep slopes contributes to its increased erosion potential.

Regarding climatic conditions, the investigated area has a continental climate with a mean annual air temperature of $10.9^{\circ} \mathrm{C}$ and a total annual precipitation of $672 \mathrm{~mm}$, based on observations between 1949 and 2011 (RHOS 2011).

In the case of the Grdelica Gorge, the harsh conditions of its deforested sites are the result of an erodible parent rock whose highly disturbed and fractured layers display varying degrees of weathering. Furthermore, skeletal and dry soils with a low $\mathrm{pH}$ have developed on the steep slopes, that led to conditions enhancing the erosion process. Interestingly, research of soil properties and soil erosion in the area of the Grdelica Gorge (Tanasijević 1956) has shown that erosion particularly occurs on soils developed on crystalline schist.
The composition of species in the area of the Grdelica Gorge is characterized by the presence of rare and fragmentary represented forest communities, as well as relict and endemorelict examples. More precisely, the most common forest type at altitudes up to $600 \mathrm{~m}$ a.s.l. in the area is the association of Turkey oak and Hungarian oak (Quercetum frainetto-cerris Rud. 1949). In addition, Montane beech forest (Fagetum moesiacae montanum Jov. 1953) is also present in this region at higher elevations, from 800 to $1300 \mathrm{~m}$ (Jovanović 1982). However, in the valley of the South Morava River, the most common communities are forests of pedunculate oak and broom (Genisto elatae-Quercetum roboris Horv. 1938) and forests of poplar and willow (Salici-Populetum albae Drees. 1936 - Tomić 2004). These associations inhabited the degraded sites at the time before deforestation occurred.

Degradation in the area of the Grdelica Gorge is a result of both natural and anthropogenic factors. Since the mid-nineteenth century, both forest destruction for agricultural purposes and negative anthropogenic impacts in this area have intensified (Djorović 2005). In particular, agriculture on deforested areas was extensive and short-term in character, as after only a few years the soils were impoverished and subsequently abandoned, resulting in the deforestation and degradation of new areas of land (Velašević \& Dorović 1998). In fact, the combination of environmental factors and strong anthropogenic impacts (deforestation) led to accelerated erosion and severe damage by frequent torrential floods (Ratknić et al. 2011).

The first recorded erosion control works in the Grdelica Gorge were conducted in 1907 , with the most extensive afforestation of the area carried out between 1956 and 1958 (Kostadinov 2007).

Due to their pioneering qualities, the two most commonly used tree species for the afforestation of extremely degraded sites in the Grdelica Gorge have been black locust (Robinia pseudoacacia L.) and black pine (Pinus nigra Arnold.). The pit planting method was applied in the very dense planting of black locust, i.e., 10000 seedlings per hectare, whereas the number of black pine seedlings per hectare reached 2500 . One section of these areas is the research object of this study, focusing on a comparative analysis of the effects of afforestation with black locust and black pine over a 60 year period. To this purpose, forests of black locust and black pine of the same age (58-60 years old) and with similar environmental conditions (climatic, orographic, edaphic, etc.) were selected as study sites.

\section{Data collection}

A total of eight sample plots (sp) were established in areas afforested with black locust and black pine in the period from 1956 to 1958 . Specifically, five sample plots (sp4, sp10, sp17, sp18 and sp21) were esta- 
blished in black locust forests and three in forests of black pine (sp5, sp11 and sp12). The sample plot sizes ranged from 0.35 ha to $0.50 \mathrm{ha}$, with an average size of $0.47 \mathrm{ha}$, as the configuration of the terrain (slope, aspect, etc.) has often hampered the establishment of plots of uniform size. The sample plots were established on crystalline schists at varying stages of weathering, with layers that were generally highly disturbed and fractured. The observed soil type was leptosol (WRB 2006), which belongs to the textural class of sandy loam, with a light mechanical composition and a weakly expressed or unexpressed structure. In order to reduce the experimental error, all sample plots were placed in areas with slopes $>20 \%$, on warm exposures (S, SW and SE), within stands $58-60$ years old that were never subjected to any silvicultural practice. In addition, no signs of plant diseases or insect attacks were observed in the plots. However, exposure and slope at the selected sites were the least favorable for the establishment of vegetation (Soljanik 1955, Okland et al. 2003, Wang \& Madley 2004).

\section{Structural and productive}

\section{characteristics of the stands}

In all plots, the diameter at breast height (d) of all trees was measured, and the height $(h)$ of 10 trees in each of the $5 \mathrm{~cm}$ increment diameter classes was recorded. To assess the structure and the production per ha of the study stands, the following parameters were derived: the number of trees $(N)$ and their distribution by diameter classes, basal area $(G)$, height curves, volume $(V)$, volume increment $(I V)$ and mean dimensions of representatives trees $(d g$, $h g$ ). The volume of specific tree for each species was calculated using a double-entry tree volume table-model type $V=f(d, h)$ and the current volume increment using the increment percentage method. The increment percentage (piv) was obtained using the model type piv $=f(d g, h g, N, s)$, where $s$ represents the share by volume of the tree species in a mixture (Banković \& Pantić 2006). Under such conditions, $s=$ 1.0, since the sampled stands were pure black locust or black pine forests.

\section{Soil and litter properties}

A total of four soil profiles were opened in each sample plot and 8 samples of litter were collected $(30 \times 30 \mathrm{~cm})$, with soil sampling carried out at fixed depths of $0-5 \mathrm{~cm}$, $5-10 \mathrm{~cm}$ and $10-20 \mathrm{~cm}$.

Basic physical and chemical properties of air-dry soil were determined using the following methods: the traditional pipette method was used for particle size analysis (Rowell 1997, ISO-11277 1998); bulk density $(B D)$ was measured on soil cores after drying at $30^{\circ} \mathrm{C}$ to a constant weight (ISO-11272 1993); soil $\mathrm{pH}$ was determined in distilled water with a solid-liquid $(\mathrm{S} / \mathrm{L})$ ratio of $1: 2.5$ $\mathrm{ml} \mathrm{g} \mathrm{g}^{-1}$, hydrolytic acidity (H meq/100 g) using Kappen's method (extraction by $\mathrm{CH}_{3}-$
COONa, titration with $0.1 \mathrm{M} \mathrm{NaOH}$ ); the sum of exchangeable basis $(S)$ also using Kappen's method (extraction by $0.1 \mathrm{M} \mathrm{HCl}$, titration with $0.1 \mathrm{M} \mathrm{NaOH}$ - Kappen 1929) and the total capacity of cation adsorption $(T)$ and degree of base saturation ( $V \%)$ were also calculated (Hissink 1925). Soil organic carbon (C) was measured using the Tjurin method (Nelson \& Sommers 1996) and total nitrogen $(\mathrm{N})$ using the Kjeldahl method (Bremner 1960, ISO-11261 1995). After extraction, the available $\mathrm{P}$ and $\mathrm{K}$ were determined by the Egner-Riehm method (Cakmak et al. 2010). All analyses were performed in 2 replicates.

\section{Soil loss}

The calculation of soil loss was performed using the Erosion Potential Method (EPM Gavrilović 1972), which was developed in Serbia and is still in use, mainly in the countries of the former Yugoslavia and the Western Balkans (Zorn \& Komac 2008, Tošić et al. 2012, Ristić et al. 2013), but also in Iran (Tangestani 2006, Bagherzadeh et al. 2011). In this study, the level of erosion was assessed based on annual soil loss ( $\left.W_{\text {year }}\right)$ immediately before afforestation $\left(W_{\text {year }} \mathrm{O}\right)$, 10 years after afforestation $\left(W_{\text {year }} 10\right)$ and 60 years after afforestation ( $\left.W_{\text {year }} 60\right)$.

\section{Carbon stock in biomass and soil}

The assessment of carbon stock in living biomass, dead wood, litter and soil was obtained using the equations recommended by the IPCC (2003), while the carbon stock in living biomass $\left(B_{\mathrm{t}}\right)$ was obtained using the following equation (eqn. 1):

$$
B_{t}=V_{t} \cdot D_{w} \cdot B E F_{2} \cdot C F \cdot(1+R)
$$

where $V_{\mathrm{t}}$ is the total bole volume $\left(\mathrm{m}^{3} \mathrm{ha} \mathrm{C}^{-1}\right)$, $D w$ is the wood density ( $M g$ dry mass $\mathrm{m}^{-3}$ green; 0.58 for black pine and 0.74 for black locust - Soškić \& Popović 2002), $B E F_{2}$ is the biomass expansion factor (dimensionless), which is the conversion factor to expand under-bark bole biomass to include non-merchantable biomass such as bark and branches (1.4 - IPCC 2003), CF is the conversion factor from dry biomass to carbon (Mg C [Mg dry mass] $]^{-1} ; 0.5$ - IPCC 2003), and $R$ is the conversion factor to include below-ground biomass (dimensionless; 0.32 for black pine and 0.26 for black locust - IPCC 2003).

The carbon stock in dead wood was assumed at a maximum of $25 \%$ of the total carbon stock in living biomass, with the maximum value estimated in this way divided by five, given that the process of decomposition takes 5 years (IPCC 2003). In addition, the carbon stock in litter was estimated as the entire dry matter of litter (IPCC 2003), whereas the carbon stock in soil $(S C D)$ was calculated using the following equation (eqn. 2 ):

$S C D=\sum_{l=1}^{l=j}\left[S O C_{\text {content }} \cdot B D \cdot \text { Depth } \cdot(1-\text { frag })\right]_{l}$ where $S C D$ is the soil carbon density for the $j$-th layers $(l)$ of the sampling site $(\mathrm{Mg} \mathrm{C}$ $\left.\mathrm{ha}^{-2}\right), S O C_{\text {content }}$ is the soil organic carbon content for a single sampled depth (\% of mass or $\left.\mathrm{g} \mathrm{k} \mathrm{kg}^{-1}\right), B D$ is the soil mass of the undisturbed volume of a single sampled depth $\left(\mathrm{t} \mathrm{m}^{-3}\right)$, Depth is the thickness of the sampled layer $(\mathrm{m})$, frag is the volume of the coarse fragments in the single sampled depth (\%).

Carbon stock was estimated in living biomass, dead wood, litter and soil in areas under black locust and black pine.

\section{Data processing}

Normal distribution of sampling data was inferred by standard skewness and kurtosis. Differences in the ameliorative effects of afforestation between black locust and black pine was tested using the Student's t-test and ANOVA $(\alpha=0.05)$. In addition, the basic physical and chemical properties of the soil in the areas afforested with black locust and black pine were compared, with soil losses and carbon stock estimated both in total and in different carbon pools (living biomass, dead wood, litter and soil). The post-hoc Fisher's LSD test and Pearson's correlation analysis were applied to test the strength of the relationship between soil $\mathrm{pH}$, total capacity of cation adsorption $(T)$, base saturation $(V \%)$ and clay content.

\section{Results}

\section{Structural and productive} characteristics of the stands

The investigated forests of black locust and black pine showed significantly differences in the production parameters (Tab. 1). Although the number of black pine trees was 5.4 times smaller, this species achieved $189.6 \%$ larger basal area, 30.8\% higher volume and 30.9\% higher current volume increment as compared with black locust. Moreover, the dimensions of the mean representative trees were also greater in the pine stands, being the mean diameter $128.2 \%$ greater and the mean height $40.7 \%$ higher than in the black locust plots. In addition, structural differences were also observed, especially with regard to diameter structure. Black locust trees were mainly represented in the thinner diameter classes with a very small variation, ranging from the $2.5 \mathrm{~cm}$ to $22.5 \mathrm{~cm}$ (with the exception of sp21, where only $1.9 \%$ of trees were represented in the diameter class > 22.5 $\mathrm{cm})$. Diameter distribution was left-skewed for black locust (Fig. 2) and right-skewed for black pine (Fig. 3), the latter species also showing a larger frequency of slightly larger diameter classes (from $7.5 \mathrm{~cm}$ to 32.5 $\mathrm{cm})$. In addition, the height curves of black locust (Fig. 4) were slightly steeper than those obtained for black pine (Fig. 5).

\section{Soil and litter properties}

A developed soil horizon A in all sample plots is an important indicator of progres- 
Tab. 1 - Characteristics of black locust and black pine stands. (1): Differences in the absolute amount; (2): Differences in percetage; (SD): Standard deviation.

\begin{tabular}{llcccccc}
\hline Species & Parameter & $\begin{array}{c}\boldsymbol{N} \\
\left(\mathrm{trees} \mathrm{ha} \mathrm{h}^{-1}\right)\end{array}$ & $\begin{array}{c}\boldsymbol{G} \\
\left(\mathrm{m}^{2} \mathrm{ha}^{-1}\right)\end{array}$ & $\begin{array}{c}\boldsymbol{d g} \\
(\mathrm{cm})\end{array}$ & $\begin{array}{c}\boldsymbol{h g} \\
(\mathrm{m})\end{array}$ & $\begin{array}{c}\boldsymbol{V} \\
\left(\mathrm{m}^{3} \mathrm{ha}^{-1}\right)\end{array}$ & $\begin{array}{c}\boldsymbol{I} \boldsymbol{v} \\
\left(\mathrm{m}^{3} \mathrm{ha}^{-1}\right)\end{array}$ \\
\hline Black & Average & 5116.6 & 15.4 & 7.1 & 9.1 & 77.6 & 5.5 \\
locust & SD & 3122.93 & 6.74 & 2.17 & 2.6 & 31.73 & 2.22 \\
& Min & 740 & 5.8 & 4.4 & 6.6 & 43.5 & 2.4 \\
& Max & 7960 & 22 & 10 & 13 & 111.2 & 7.9 \\
\hline \multirow{5}{*}{ Black pine } & Average & 794.1 & 44.6 & 16.2 & 12.8 & 101.5 & 7.2 \\
& SD & 121.3 & 50.44 & 0.49 & 1.53 & 26.5 & 1.79 \\
& Min & 658 & 13 & 15.9 & 11.2 & 74.4 & 5.4 \\
& Max & 900 & 102.8 & 16.9 & 14.3 & 127.4 & 9 \\
\hline \multirow{2}{*}{ Difference } & 1 & -4322.5 & 29.2 & 9.1 & 3.7 & 23.9 & 1.7 \\
& 2 & -544.3 & 189.6 & 128.2 & 40.7 & 30.8 & 30.9 \\
\hline
\end{tabular}

sive soil processes. Taking into consideration that the investigated stands were of the same age and that afforestation was carried out on soils with very sparse and stunted vegetation or no vegetation at all, the presence of the horizon $A$ is indicative of the ameliorative effects of afforestation on the process of pedogenesis.

Soil reaction $(\mathrm{pH}$ in water) in the $0-5 \mathrm{~cm}$ layer was weakly to moderately acidic, while it was moderately to strongly acidic in deeper layers. Although the $0-5 \mathrm{~cm}$ soil layer was moderately humous (3-5\%), the lower layers of the profile were only mildly

Concerning the nutrient content in the studied soil, the following values were recorded: the total $\mathrm{N}$ ranged from 0.44 to humous $(1-3 \%)$.
$0.16 \%$, indicating a soil well supplied with $\mathrm{N}$, while the content of available $P$ was very low and the available $K$ was medium to high.

Tab. 2 shows the basic soil characteristics of the areas afforested with the two different species. No significant differences between the soil samples of the two species were found with respect to clay content, hydrolytic acidity (Y1), humus content, $\mathrm{C}, \mathrm{C} / \mathrm{N}$, available $\mathrm{P}$ and available $\mathrm{K}$. However, differences were statistically significant when the total $\mathrm{N}$ content, the total capacity of cation adsorption $(\mathrm{T})$ and base saturation (V\%) were considered. In particular, the total capacity of cation adsorption $(\mathrm{T})$ and base saturation (V\%) were significantly higher in the soils under black pine as compared with those under black locust. Moreover, the values of the above parameters decreased with depth, especially in the soil layers deeper than $5 \mathrm{~cm}$ under black locust. Furthermore, the $0-5$ $\mathrm{cm}$ soil layer under black locust was significantly richer in total $\mathrm{N}$ compared to the soils afforested with black pine, whereas

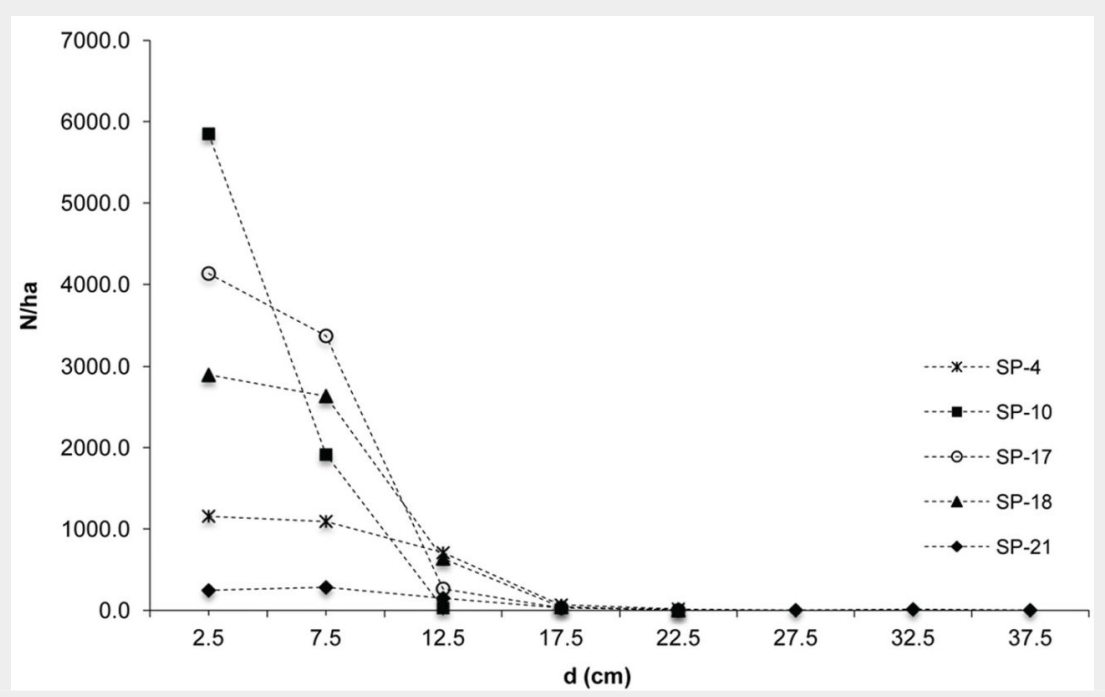

Fig. 2 - The diameter distribution of black locust.

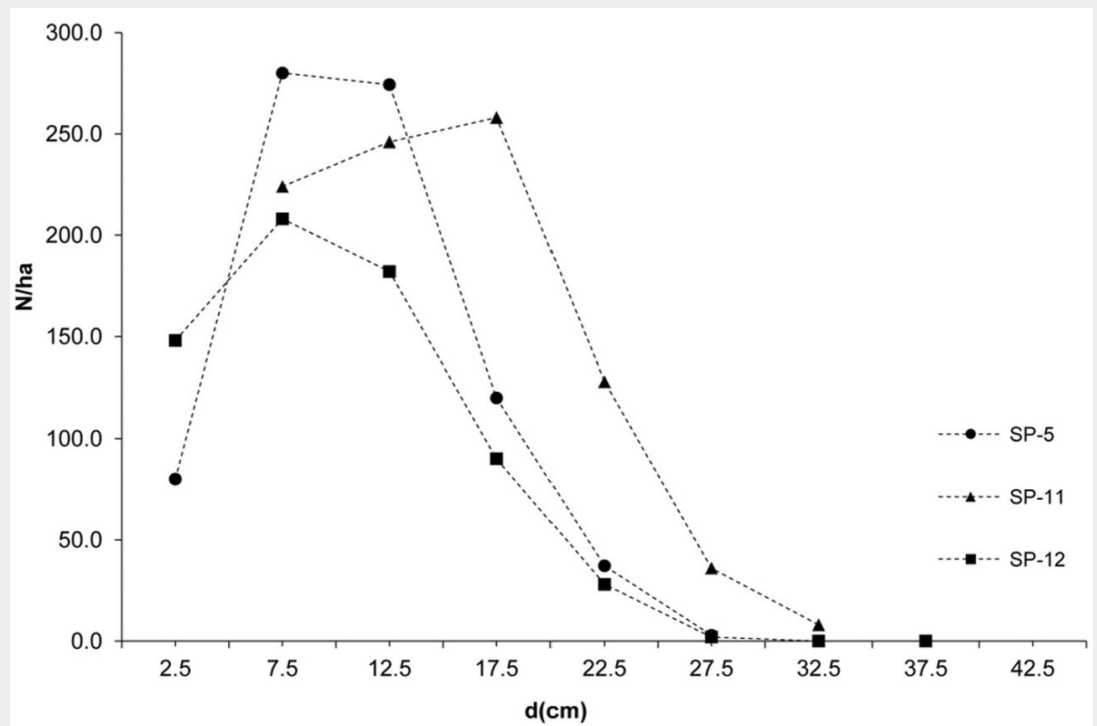

Fig. 3 - The diameter distribution of black pine. 
Fig. 4 - Height curves of black locust.

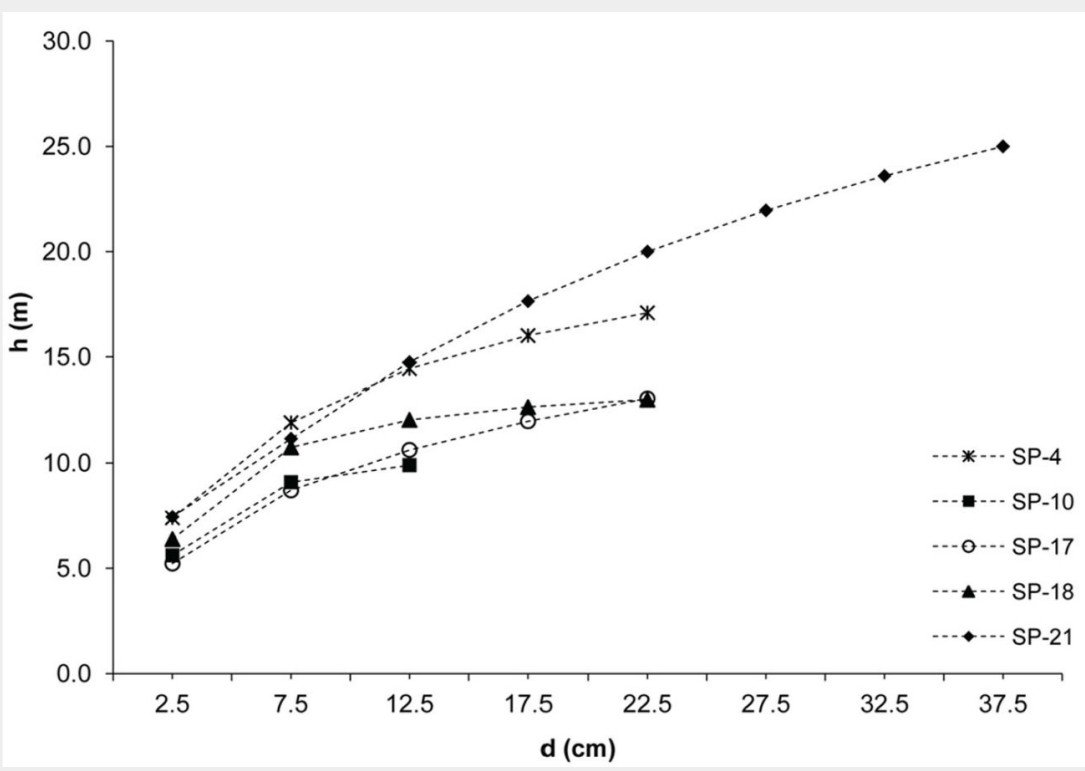

Fig. 5 - Height curves of black pine.

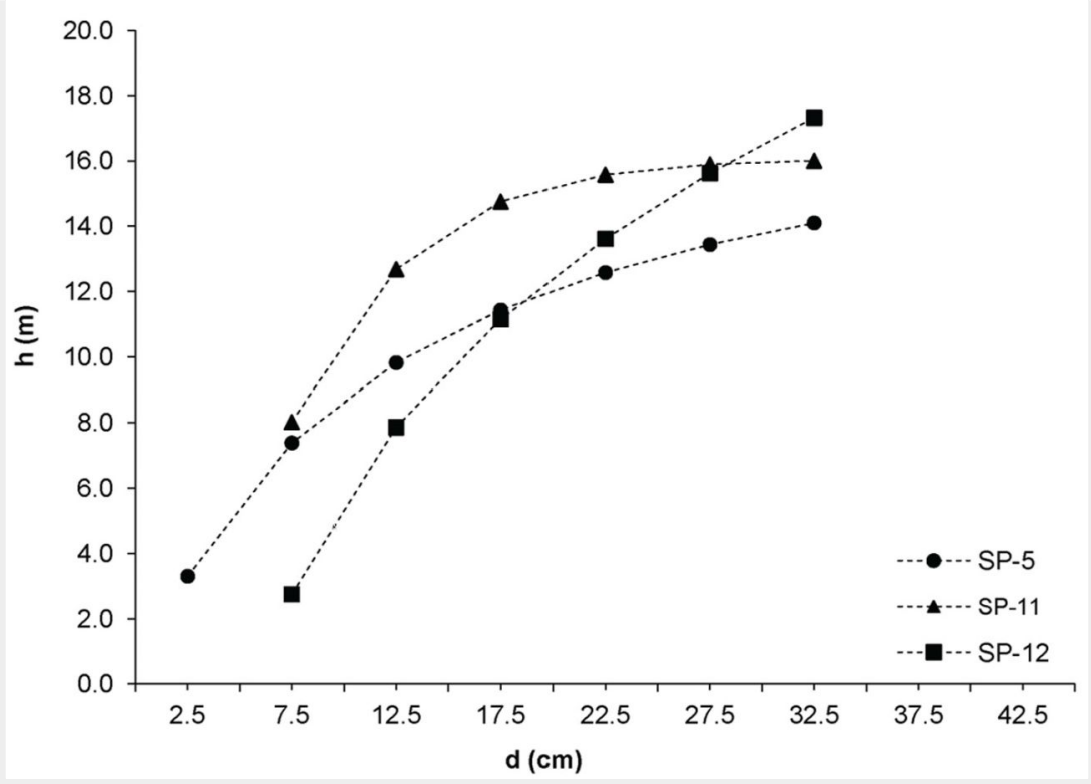

no significant differences were observed in the 5-10 cm layer.

As for soil pH in the $5-10 \mathrm{~cm}$ and $10-20 \mathrm{~cm}$ layers, black locust soil samples showed values significantly lower than those of pine soil samples, while no significant dif- ferences were found for the $0-5 \mathrm{~cm}$ layer samples. Soil $\mathrm{pH}$ under black locust considerably decreases with depth, with values of $6.00 \pm 0.2,5.56 \pm 0.1$ and $5.34 \pm 0.2$ in the 0-5 cm, $5-10 \mathrm{~cm}$ and $10-20 \mathrm{~cm}$ layers, respectively. Similarly, soil pH under black pine decreases with depth, although this is less pronounced: at depths of $0-5,5-10$ and $10-$ $20 \mathrm{~cm}$, the pH value was $6.30 \pm 0.4,6.02 \pm$ $0.3 \mathrm{~cm}$ and $5.80 \pm 0.2$, respectively (Tab. 3 ). Litter properties have a significant impact on the soil. When the basic properties of

Tab. 2 - Basic soil properties at different depths in black locust and black pine stands. $\left({ }^{*}\right): p<0.05 ;(* *): p<0.01$.

\begin{tabular}{|c|c|c|c|c|c|c|}
\hline \multirow{2}{*}{$\begin{array}{l}\text { Soil } \\
\text { Properties }\end{array}$} & \multicolumn{3}{|c|}{ Black locust } & \multicolumn{3}{|c|}{ Black pine } \\
\hline & $0-5 \mathrm{~cm}$ & $5-10 \mathrm{~cm}$ & $10-20 \mathrm{~cm}$ & $0-5 \mathrm{~cm}$ & $5-10 \mathrm{~cm}$ & $10-20 \mathrm{~cm}$ \\
\hline Clay \% & $8.40 \pm 2.8$ & $11.40 \pm 4.1$ & $11.30 \pm 2.8$ & $6.30 \pm 0.4$ & $16.40 \pm 3.6$ & $17.60 \pm 3.5$ \\
\hline $\mathrm{pH}$ & $6.00 \pm 0.2$ & $5.56 \pm 0.1$ & $5.34 \pm 0.2$ & $6.30 \pm 0.4$ & $6.02 \pm 0.3^{*}$ & $5.80 \pm 0.2^{*}$ \\
\hline Y1 & $15.20 \pm 3.3$ & $15.00 \pm 2.2$ & $17.00 \pm 1.4$ & $10.50 \pm 3.4$ & $12.60 \pm 2.6$ & $13.50 \pm 2.3$ \\
\hline $\mathrm{T}$ & $20.51 \pm 4.0$ & $14.30 \pm 2.9$ & $12.25 \pm 0.9$ & $26.96 \pm 2.1^{* *}$ & $24.26 \pm 0.7^{* *}$ & $25.03 \pm 1.8^{* *}$ \\
\hline V (\%) & $49.54 \pm 17.9$ & $26.34 \pm 12.4$ & $9.82 \pm 0.7$ & $74.18 \pm 9.8^{*}$ & $66.20 \pm 6.6^{* *}$ & $63.92 \pm 5.1^{* *}$ \\
\hline Humus & $5.34 \pm 1.3$ & $2.14 \pm 0.4$ & $1.51 \pm 0.3$ & $4.37 \pm 1.4$ & $2.78 \pm 0.6$ & $2.04 \pm 0.3$ \\
\hline N (\%) & $0.305 \pm 0.05^{*}$ & $0.165 \pm 0.02$ & - & $0.213 \pm 0.04$ & $0.177 \pm 0.07$ & - \\
\hline $\mathrm{C} / \mathrm{N}$ & $10.10 \pm 1.3$ & $8.60 \pm 0.8$ & - & $11.80 \pm 2.3$ & $9.50 \pm 1.4$ & - \\
\hline$P(\mathrm{mg} / \mathrm{g})$ & $2.45 \pm 1.7$ & $1.65 \pm 1.6$ & - & $3.40 \pm 1.2$ & $4.70 \pm 3.2$ & - \\
\hline$K$ & $33.40 \pm 7.7$ & $31.20 \pm 8.0$ & $19.40 \pm 6.8$ & $23.10 \pm 8.6$ & $23.60 \pm 14.8$ & $18.20 \pm 11.6$ \\
\hline
\end{tabular}


Tab. 3 - Soil pH in the layers at different depths in black locust and black pine stands. (1): " $x$ " in the same column denotes the absence of differences between the average values of the tested groups; " $x$ " in different vertical planes denotes the existence of differences between the average values of the tested groups.

\begin{tabular}{lcccc}
\hline \multirow{2}{*}{ Soil layer } & \multicolumn{2}{c}{ Black locust } & \multicolumn{2}{c}{ Black pine } \\
\cline { 2 - 5 } & Average & Differences $^{1}$ & Average & Differences $^{1}$ \\
\hline $0-5 \mathrm{~cm}$ & 6.00 & $\times-$ & 6.30 & $\times-$ \\
$5-10 \mathrm{~cm}$ & 5.56 & $-\times$ & 6.02 & $\times \times$ \\
$10-20 \mathrm{~cm}$ & 5.34 & $-\times$ & 5.80 & $-\times$ \\
Stats & $\mathrm{F}=12.36 ; \mathrm{p}=0.005$ & $\mathrm{~F}=2.88 ; \mathrm{p}=0.099$ \\
\hline
\end{tabular}

Tab. 4 - Properties of litter in black locust and black pine stands. (ns): not significant.

\begin{tabular}{lccc}
\hline Soil property & Black locust & Black pine & Prob. \\
\hline Average amount of forest litter $\left(\mathrm{kg} \mathrm{m}^{-2}\right)$ & $1.975 \pm 0.84$ & $2.695 \pm 1.75$ & $\mathrm{~ns}$ \\
pH & $6.54 \pm 0.1^{* *}$ & $5.31 \pm 0.3$ & $<0.01$ \\
Humus $(\%)$ & $60.68 \pm 8.6$ & $82.19 \pm 4.0^{* *}$ & $<0.01$ \\
$\mathrm{C}(\%)$ & $35.17 \pm 4.9$ & $47.50 \pm 2.3^{* *}$ & $<0.01$ \\
$\mathrm{~N}(\%)$ & $1.662 \pm 0.2^{* *}$ & $1.003 \pm 0.2$ & $<0.01$ \\
$\mathrm{C} / \mathrm{N}$ & $21.2 \pm 2.0$ & $50.6 \pm 17.4^{*}$ & $<0.05$ \\
\hline
\end{tabular}

Tab. 5 - Estimated soil losses in areas reforested with black locust and black pine. (1): " $\times$ " in the same vertical plane denotes the absence of differences between the average values of the tested groups; " $\times$ " in different vertical planes denotes the existence of differences between the average values of the tested groups.

\begin{tabular}{lcccc}
\hline \multirow{2}{*}{$\mathrm{W}_{\mathrm{yr}}$} & \multicolumn{2}{c}{ Black locust } & \multicolumn{2}{c}{ Black pine } \\
\cline { 2 - 5 } & Average & Differences $^{1}$ & Average & Differences $^{1}$ \\
\hline $\mathrm{W}_{\mathrm{yr} 0} 0$ & 53.80 & $\times--$ & 49.81 & $\times-$ \\
$\mathrm{W}_{\mathrm{yr} 10}$ & 15.68 & $-\times-$ & 12.08 & $-\times$ \\
$\mathrm{W}_{\mathrm{y} 60} 60$ & $-\times$ & 5.02 & $-\times$ \\
Stats & 4.32 & $\mathrm{~F}=40.81 ; \mathrm{p}=0.000$ \\
\hline
\end{tabular}

Tab. 6 - C stock in biomass and soil in black locust and black pine stands. (ns): not sig nificant.

\begin{tabular}{|c|c|c|c|c|c|}
\hline \multirow{2}{*}{ C pools } & \multicolumn{2}{|c|}{ Black locust } & \multicolumn{2}{|c|}{ Black pine } & \multirow{2}{*}{ Prob. } \\
\hline & $\mathrm{Mg} \mathrm{ha}^{-1}$ & $\%$ & Mg ha $^{-1}$ & $\%$ & \\
\hline Living biomass & $45.4 \pm 28.1$ & 43 & $57.3 \pm 6.4$ & 43 & ns \\
\hline Dead wood & $17.4 \pm 12.0$ & 16 & $22.3 \pm 2.6$ & 17 & ns \\
\hline Litter & $19.8 \pm 10.0$ & 18 & $27.2 \pm 19.2$ & 21 & ns \\
\hline Soil & $24.6 \pm 5.6$ & 23 & $24.6 \pm 13.7$ & 19 & ns \\
\hline Total C stock & $107.2 \pm 56.0$ & 100 & $131.5 \pm 33.2$ & 100 & ns \\
\hline
\end{tabular}

litter of the two species used for afforestation were compared (Tab. 4), it was found that the $\mathrm{pH}$ and $\mathrm{N}$ content were significantly higher in the black locust litter than in the black pine litter. However, humus, $C$ contents and $\mathrm{C} / \mathrm{N}$ ratio were higher in the black pine litter.

\section{Soil loss}

In areas under black locust, estimates of soil loss have been significantly reducing since the period of afforestation, the period of the first ten years after afforestation and in the subsequent period up to the present day $(53.80,15.68$ and $4.32 \mathrm{Mg}$ $\mathrm{km}^{2} \mathrm{yr}^{-1}$, respectively). Analogously, soil loss estimates in black pine stands were significantly reduced from 49.81 to $12.08 \mathrm{Mg} \mathrm{km}^{2}$ $\mathrm{yr}^{-1}$ in the first 10 years after afforestation. However, the reduction of soil loss in the subsequent period up to present $(5.02 \mathrm{Mg}$ $\mathrm{km}^{2} \mathrm{yr}^{-1}$ ) was not statistically significant (Tab. 5).

\section{Carbon stock in biomass and soil}

The sequestration of atmospheric carbon in biomass and soil is one of the ecosystem services provided by afforestation and is of particular importance for degraded and harsh habitats. In this study, the estimate of the total C stock was 107.2 $\pm 56.0 \mathrm{Mg} \mathrm{ha}^{-1}$ in black locust and $131.5 \pm 33.2 \mathrm{Mg} \mathrm{ha}^{-1}$ in black pine. In particular, the largest amount of $C$ stock was found in the living biomass: $45.4 \pm 28.1 \mathrm{Mg} \mathrm{ha}^{-1}$ in black locust and $57.3 \pm 6.4 \mathrm{Mg} \mathrm{ha}^{-1}$ in black pine (Tab. 6). Although no significant differences in carbon stocks were found between the two species considered, the ability of such species to sequester $C$ was apparent.

\section{Discussion}

The extreme nature of the Grdelica Gorge habitat is equally reflected both in the natural conditions of specific sites in this area and the anthropogenic factors that contribute to the creation of the harsh condi- tions. In particular, the natural factors that make the sites of the Grdelica Gorge extreme are its highly dissected relief, the uneven distribution of rainfall, the occurrence of high intensity rainstorms, as well as early autumn and late spring frosts. Additional factors are the parent rock highly susceptible to weathering and the soils having generally a light texture and weakly pronounced structure. Such natural conditions combined with negative anthropogenic impacts foster erosion processes in the soils of the Grdelica Gorge. Uncontrolled and unplanned deforestation, together with inappropriate land use practices in the area, have contributed to the manifestation of the Grdelica Gorge's extreme habitat.

Afforestation in the area of the Grdelica Gorge was primarily conducted for the purpose of erosion control. This study is an attempt to comprehend the ameliorative effects of such afforestation after 60 years and to compare the effects of the two most commonly species used for contrasting the erosion. In this respect, we focused onto the impact of black locust and black pine on soil properties, soil losses caused by erosion and $C$ stock in the restored forest ecosystem, as well as on their structural and productive characteristics. Our results suggest that certain indicators of the ameliorative effects of afforestation may differ depending on the species selected.

\section{Structural and productive characteristics of forests}

Given the uniform habitat conditions and the lack of previous silvicultural treatments, black pine performed significantly better than black locust. In addition to the biological characteristics of the species, this could be due to the current high density of black locus stands, reaching over 5000 trees per hectare, with a very slow differentiation in diameter. Indeed, this is reflected by the high frequency observed in thinnest diameter classes and the high degree of tree slenderness ( $h g / d g$ over 1.2) found in the black locust stands, caused by an intense height increment. In this context, the thinning of black locust forests is a necessary silvicultural measure to be taken urgently. The reduction in the number of trees would promote the expansion of tree canopies and roots, with an expected positive impact on the stabilization of these soils.

\section{Soil and litter properties}

Previous research confirmed that afforestation does reduce the soil pH (Panagopoulos \& Hatzistathis 1995, Groenendijk et al. 2002, Jobbagy \& Jackson 2003). Our results indicate that soil layers deeper than $5 \mathrm{~cm}$ are significantly more acidic under black locust than under black pine, while no significant differences in acidity were found for $0-5 \mathrm{~cm}$ soil layers. Although the soils under the black locust and black pine 
are of same type, localities afforested with black locust are slightly more acidic than those with black pine. This may be partly due to the fact that when the afforestation was conducted, slightly more acidic localities were planted with black locust rather than with black pine. Moreover, a significantly higher $\mathrm{pH}$ value was found in the $0-5$ $\mathrm{cm}$ soil layer when compared to the 5-10 $\mathrm{cm}$ and $10-20 \mathrm{~cm}$ soil layers of black locust stands, while in black pine stands no significant differences in $\mathrm{pH}$ values were found between adjacent soil layers. The higher soil $\mathrm{pH}$ of shallow layers under black locust trees can be explained by the litter characteristics, whose $\mathrm{pH}$ is almost neutral (6.54 \pm 0.1 ), whereas the litter of black pine is acidic $(5.31 \pm 0.3)$, and the difference in acidity is statistically significant $(p<0.001)$. In addition, black locust litter has a higher decomposition rate (Tateno et al. 2007), and the mode of litter decomposition of black locust affects the quality of the organic matter that accumulates in the mineral soil layer (De Marco et al. 2012). Given its pH-neutrality, fast decomposition and the incorporation of quality organic matter into mineral soil layers, we can assume that such characteristics may contribute to an increase in $\mathrm{pH}$ of the surface soil layer under black locust.

In this study the degree of base saturation $(V \%)$ was positively correlated with soil $\mathrm{pH}$ under both black locust $(r=0.961, \mathrm{p}=$ $0.024)$ and black pine $(r=0.996, \mathrm{p}<0.001)$. It has been reported that $\mathrm{pH}$ reaction is a good indicator of $V \%$ in moderately acidic to neutral soils (Härdtle et al. 2004). The soil $\mathrm{pH}$ under black pine is higher and, therefore, their base saturation is also expected to be higher. As a result, the total capacity of cation adsorption is significantly higher in soils under black pine. In the case of soils under black locust, the total capacity of cation adsorption is correlated with $\mathrm{pH}(r=0.961, \mathrm{p}=0.039)$ and clay content $(r=0.998, \mathrm{p}=0.002)$, while in soils under black pine the total capacity of cation adsorption is not correlated with these parameters.

The soils under black locust had a significantly higher total $\mathrm{N}$ content than those under black pine, and the total $\mathrm{N}$ content in the studied area decreased with soil depth. In fact, nitrogen fixation by black locust trees may explain the higher total $\mathrm{N}$ soil content, as well as the properties of the species' litter, the mode of its transformation (De Marco et al. 2012) and its mineralization rate (Rice et al. 2004, Tateno et al. 2007). In particular, the litter of black locust contained significantly more $\mathrm{N}$ $(1.662 \pm 0.2 \%)$ than that of black pine $(1.003$ $\pm 0.2 \%$ ). Tateno et al. (2007) reported that the litter of black locust aged 20-30 years contained $1.49 \%$ of $\mathrm{N}$.

The $\mathrm{C} / \mathrm{N}$ ratio is an indicator of the transformation rate of organic matter. According to our results, the $\mathrm{C} / \mathrm{N}$ ratio was $21.2 \pm$ 1.9 in the black locust litter, which is considerably more favorable than the ratio of
31.9 reported by Tateno et al. (2007). Furthermore, the $\mathrm{C} / \mathrm{N}$ ratio in black locust litter was significantly smaller than that in the litter of black pine $(50.6 \pm 17.4)$. A smaller $\mathrm{C} / \mathrm{N}$ ratio $(<20)$ indicates a faster litter decomposition and mineralization of organic $\mathrm{N}$ (Rice et al. 2004), which is then incorporated into the surface soil layer, resulting in a higher $\mathrm{N}$ content of soils in black locust stands.

\section{Soil loss}

The characteristics of vegetation affect soil erosion and water runoff (Zhang et al. 2004, Zheng 2006, Chirino et al. 2006, Durán Zuazo et al. 2006, Huang et al. 2010). According to Zhou et al. (2006), soil erosion shows a negative linear correlation with the vegetation cover. The results of this study showed that the estimated soil losses in the afforested areas were drastically reduced. Comparing the estimates of soil loss immediately before afforestation (Tanasijević 1956) with those of 10 years later, a reduction by $76 \%$ and $71 \%$ was estimated in the soils under black pine and black locust, respectively. In the subsequent period up to the present day, the soil loss under black pine has been reduced by $58 \%$, while it decreased by $72 \%$ under black locust. Durán Zuazo et al. (2006) reported a $58-98 \%$ reduction in soil loss in areas covered with different types of vegetation compared to areas with no vegetation, while Chirino et al. (2006) suggested a decrease up to $70-95 \%$. In this study, a significant reduction of soil losses in the first 10 years after afforestation of black pine stands was observed, while such reduction was not statistically significant in the subsequent period up to present. However, the reduction of soil loss under black locust is statistically significant in all the observation periods. Therefore, it can be concluded that black locust gradually and constantly contributes to a reduction of soil loss. The efficiency of this species in preventing the erosion may be related to the improvement of several soil properties, such as $\mathrm{N}$ content or $\mathrm{C} / \mathrm{N}$, thus reducing soil erodibility. The beneficial impact of black locust on soil properties increases with stand age (Qiu et al. 2010), making it a very effective species for continuous erosion control over a long time period.

The selection of species for the afforestation of barren and/or severely eroded land may have beneficial effects on erosion control by reducing the soil and nutrient loss (Rhoades et al. 1998, Zhang et al. 2004). Zhang et al. (2003) emphasize the efficiency of black locust against erosion, while Cao et al. (2007) reported that black locust was an effective species in the conservation of underdeveloped land. Wang et al. (2014) explored the impact of soil erodibility on nutrient losses, reporting that total $\mathrm{N}$ loss is mainly controlled by the rate of runoff and sediment yield (soil loss). In this study, the reduction of soil loss and the increase in total $\mathrm{N}$ indicate the effec- tiveness of black locust in erosion control.

\section{Carbon stock in biomass and soil}

Afforestation, forest restoration and suitable forest management practices are powerful strategies for the mitigation of climate change through atmospheric $C$ sequestration in biomass and soil (Marland \& Marland 1992, Moffat 1997, Ingham 2000). The potential of carbon sequestration depends on the type of afforestation, environmental conditions and modes of management (Fang et al. 2007). According to Lal (2005), total carbon stock under a 27-yearold oak forest is $117 \mathrm{t} \mathrm{ha}^{-1}$, and $227 \mathrm{t} \mathrm{ha}^{-1}$ under a 69-year old forest of oak and beech. The total carbon stock in the area of the Grdelica Gorge (107.2 t ha ${ }^{-1}$ for black locust and $131.5 \mathrm{t} \mathrm{ha}^{-1}$ for black pine) is remarkable, considering that the afforestation was carried out on abandoned and degraded land. Based on our results, there is no significant differences either in the total $C$ stock or in the $C$ stock of carbon pools between black locust and black pine forests (Tab. 6). However, the percentages of $C$ stock in pools differ between black pine and black locust. The share of C stock in living biomass is $43 \%$ in both black locust and black pine. In black locust the share of C stock in dead wood is $16 \%$, whereas in black pine this share accounts for $17 \%$. Ouimet et al. (2007) reported that the share of $C$ stock in living biomass accounted for as much as $71 \%$ of the total C stock in 22 -yearold plantations of Pinus resinosa Ait.

In this study, the share of the total $C$ stock found in litter and soil of black locust stands differed from that of black pine stands. The $C$ stock in litter was greater in the afforestation with black pine (21\% vs. $18 \%$ ), whereas the soil $\mathrm{C}$ stock was greater in the afforestation with black locust (23\% vs. $19 \%$ ). The greater share of C stock in the litter of black pine can be associated with the slower decomposition of the black pine litter which accumulates on the soil surface (De Marco et al. 2012).

According to Dixon et al. (1994), forest soils contain approximately $40 \%$ of the total above-ground carbon and represent an important pool for its sequestration (Jobbagy \& Jackson 2003, Lal 2005). The greater share of $C$ stock in soil under black locust (23\%) as compared with that under black pine (19\%) may be associated with the soil properties under the former species, which affect the carbon sequestration performances of the soil. As a broadleaved, nitrogen-fixing species, black locust provides a greater accumulation of carbon in the soil (Paul et al. 2002). Given that the rate of litter decomposition of nitrogen-fixing species is higher than in other species (O'Connell \& Sankaran 1997), this may increase the rate of $C$ accumulation in the soil under black locust (Paul et al. 2002). Moreover, in areas covered with black locust where erosion processes are less pronounced, the conditions for $C$ sequestration tend to be more favorable. 


\section{Conclusion}

The results of this study indicate that under extremely harsh habitat conditions, the tree species analyzed have different impacts on several soil properties, as well as on the erosion control and the $C$ stock. Black locust performed better than black pine, leading to the following beneficial effects: (i) the $\mathrm{N}$ enrichment of the surface soil and a higher total $\mathrm{N}$ soil content; (ii) a decrease in the acidity of the surface soil layers and an increase in $\mathrm{pH}$ of the $0-5 \mathrm{~cm}$ layer; (iii) a long-term erosion control through a continuous reduction of soil loss; (iv) an improvement of soil conditions for $\mathrm{C}$ sequestration, and a greater share of the total C stock in soil. On the other hand, black pine achieved significantly higher production (basal area, volume, current volume increment, mean diameter, mean height), thereby showing a greater efficiency in $C$ sequestration, particularly in living biomass.

Regarding forest ecosystem restoration, black locust is more efficient than black pine, in that its impact on the soil creates favorable conditions, thus promoting the re-establishment of the original forest. Considering that afforestation in the study area was primarily aimed at erosion control and was conducted on highly exhausted soil damaged by erosion, the ameliorative effects of the selected species, especially those of black locust, are obvious. In conclusion, it can be stated that black locust is a more suitable species for the afforestation of degraded land in the examined area.

Knowledge of the impact of different species on the mitigation of harsh habitat conditions can provide guidelines for the selection of species to be used in future afforestation activities aimed at the restoration of degraded forest sites. Moreover, an appropriate selection of species for afforestation of degraded land may help land use managers in achieving optimal benefits and ecosystem services.

\section{Acknowledgements}

We are grateful to the Ministry of Education and Science of the Republic of Serbia for their financial support through the projects: "Climate Change and Its Impact on the Environment - Monitoring, Adaptation and Mitigation", reference no. 043007 and "Sustainable management of total forest potential in the Republic of Serbia", reference no. 37008. The authors would also like to thank two anonymous reviewers for their helpful suggestions.

\section{References}

Andrés C, Ojeda F (2002). Effects of afforestation with pines on woody plant diversity of Mediterranean heathlands in southern Spain. Biodiversity and Conservation 11: 1511-1520. doi: 10.1023/A:1016850708890

Bagherzadeh A, Reza M, Daneshvar M (2011). Sediment yield assessment by EPM and PSIAC models using GIS data in semi-arid region. Fron- tiers of Earth Science 5 (2): 207-216. - doi: 10.10 07/s11707-011-0168-z

Banković S, Pantić D (2006). Dendrometrija [Dendrometry]. Univerzitet u Beogradu, Šumarski fakultet, Belgrade, Serbia, pp. 556. [in Serbian]

Barčić D, Hršak V, Španjol Z (2006). The ameliorative effects of pine cultures on forest sites on the island of Rab in Southwest Croatia. Forest Ecology and Management 237: 39-46. - doi: 10.1016/j.foreco.2006.09.065

Blanco-Canqui H, Lal R (2008). Principles of soil conservation and management. Springer Science+Business Media BV, The Netherlands, pp. 620. [online] URL: http://books.google.com/ books?id=6IKHXc6ARywC

Bremner JM (1960). Determination of nitrogen in soil by Kjeldahl method. Journal of Agricultural Science 55: 1-23. - doi: 10.1017/So0218596 00021560

Cao S, Chen L, Xu C, Liu Z (2007). Impact of three soil types on afforestation in China's Loess Plateau: growth and survival of six tree species and their effects on soil properties. Landscape and Urban Planning 83: 208-217. - doi: 10.1016/j. landurbplan.2007.04.006

Chirino E, Bonet A, Bellot J, Sánchez JR (2006). Effects of 30-year-old Aleppo pine plantations on runoff, soil erosion, and plant diversity in a semi-arid landscape in south eastern Spain. Catena 65: 19-29. - doi: 10.1016/j.catena.2005.09. 003

Cakmak D, Saljnikov E, Mrvić V, Jakovljević M, Marjanović Z, Sikirić B, Maksimović S (2010). Soil properties and trace elements contents following 40 years of phosphate fertilization. Journal of Environmental Quality 39 (2): 541547. - doi: 10.2134/jeq2009.0216

De Marco A, Spaccini R, Vittozzi P, Esposito F, Berg B, Virzo De Santo A (2012). Decomposition of black locust and black pine leaf litter in two coeval forest stands on Mountain Vesuvius and dynamics of organic components assessed through proximate analysis and NMR spectroscopy. Soil Biology and Biochemistry 51: 1-15. doi: 10.1016/j.soilbio.2012.03.025

Dixon RK, Brown S, Houghthon RA, Solomon AM, Trexler MC, Wisniewski J (1994). Carbon pools and flux of global forest ecosystems. Science 263 (5144): 185-190. - doi: 10.1126/science. 263.5144 .185

Durán Zuazo HV, Francia Martínez JR, Rodríguez Pleguezuelo CR, Martínez Raya A, Carcéles Rodríguez B (2006). Soil-erosion and runoff prevention by plant covers in a mountainous area (SE Spain): implications for sustainable agriculture. Environmentalist 26: 309-319. - doi: 10.1007/s10669-006-0160-4

Djorović M, Isajev V, Kadović R (2003). Systems of afforestation and grass cover in erosion control. Faculty of Forestry, University of Banja Luka, Republic of Srpska, Bosnia and Hertzegovina, pp. 402.

Djorović M (2005). Vodna i eolska erozija zemljišta [Water and wind soil erosion]. Acta Biologica Jugoslavica, Unija bioloških naučnih društava Jugoslavije, Belgrade, Serbia, pp. 440. [in Serbian]

El-Keblawy A, Ksiksi T (2005). Artificial forests as conservation sites for the native flora of the UAE. Forest Ecology and Management 213: 288-
296. - doi: 10.1016/j.foreco.2005.03.058 Fang S, Xue J, Tang L (2007). Biomass production and carbon sequestration potential in poplar plantations with different management patterns. Journal of Environmental Management 85: 672-679. - doi: 10.1016/j.jenvman.20006.09. 014

Gavrilović S (1972). Engineering of torrents and erosion. Journal of Construction, Special Issue, Belgrade, Serbia, pp. 292.

Groenendijk FM, Condron LM, Rijkse WC (2002). Effects of afforestation on organic carbon, nitrogen and sulfur concentrations in New Zealand hill country soils. Geoderma 108: 91-100. doi: 10.1016/So016-7061(02)00125-8

Härdtle W, Von Oheimb G, Friedel A, Mayer $\mathrm{H}$, Westphal C (2004). Relationship between $\mathrm{pH}$ values and nutrient availability in forest soils the consequences for the use of ecograms in forest ecology. Flora 199: 134-142. - doi: 10.1078/ 0367-2530-00142

Hissink DJ (1925). Base exchange in soils. Transactions of the Faraday Society 20: 551-556 - doi: 10.1039/tf9252000551

Huang Z, Ouyang Z, Li F, Zheng H, Wang X (2010). Response of runoff and soil loss to reforestation and rainfall type in red soil region of southern China. Journal of Environmental Sciences 22 (11): 1765-1773. - doi: 10.1016/S10010742(09)60317-X

Ingham CD (2000). Carbon forestry: encouraging the positives. Journal of Forestry 98 (9): 3.

IPCC (2003). Good practice guidance for land use, land-use change and forestry (Penman J, Gytarsky M, Hiraishi T, Krug T, Kruger D, Pipatti R, Buendia L, Miwa K, Ngara T, Tanabe K, Wagner $F$ eds). IPCC, Institute for Global Environmental Strategies (IGES), Kanagawa, Japan, pp. 593. [online] URL: http://www.ipcc-nggip.iges. or.jp/public/gpglulucf/gpglulucf_files/GPG_LUL UCF_FULL.pdf

ISO-11261 (1995). Soil quality - Determination of total nitrogen, modified Kjeldahl method. International organization for standardization, Geneva, Switzerland, pp. 4.

ISO-11272 (1993). Soil quality - Determination of dry bulk density. International organization for standardization, Geneva, Switzerland, pp. 10. ISO-11277 (1998). Soil quality - Determination of particle size distribution in mineral soil material. Method by sieving and sedimentation. International organization for standardization, Geneva, Switzerland, pp. 34.

Jobbagy EG, Jackson RB (2003). Patterns and mechanisms of soil acidification in the conversion of grassland to forest. Biogeochemistry 64: 205-229. - doi: 10.1023/A:1024985629259 Jovanović B (1982). Dendrologija [Dendrology]. Univerzitet u Beogradu - Šumarski fakultet, Belgrade, Serbia, pp. 713. [in Serbian]

Kappen H (1929). Die Bodenazidität [The soil acidity]. Springer Verlag, Berlin, Germany, pp. 363. [in German]

Kostadinov S (2007). Erosion and torrent control in Serbia: hundred years of experiences. In: Proceedings of the International Conference "Erosion and Torrent Control as a Factor in Sustainable River Basin Management" (Kostadinov S, Bruk S, Walling D eds). Belgrade (Serbia), 2528 Sep 2007. University of Belgrade, Faculty of Forestry, Belgrade, Serbia, pp. 1-14. 
Lal R, Kimble JM, Birdsey RA, Heath LS (2003). Research and development priorities for carbon sequestration in forest soils. In: "The Potential of US Forest Soils to Sequester Carbon and Mitigate the Greenhouse Effect" (Kimble JM, Heath LS, Birdsey RA, Lal R eds). CRC Press, Boca Raton, FL, USA, pp. 409-420.

Lal R (2005). Forest soils and carbon sequestration. Forest Ecology and Management 220: 242258. - doi: 10.1016/j.foreco.2005.08.015

Marland G, Marland S (1992). Should we store carbon in trees? Water, Air, and Soil Pollution 64: 181-195. - doi: 10.1007/BF00477101

McNeely JA (2005). Managing the risk of invasive alien species in restoration. In: "Forest restoration in landscapes: Beyond planting trees" (Mansourian S, Vallauri D, Dudly N eds). Springer, New York, USA, pp. 345-349. - doi: 10.1007/ 0-387-29112-1_49

Moffat AS (1997). Resurgent forests can be greenhouse gas sponges. Science 277: 315-316. doi: $10.1126 /$ science.277.5324.315

Nelson DW, Sommers LE (1996). Total carbon, organic carbon and organic matter. In: "Methods of soil analysis. Part 3 - Chemical Methods" (Sparks DL ed). SSSA Book Series No. 5, SSSA and ASA, Madison, WI, USA, pp. 961-1010. [online] URL: https://dl.sciencesocieties.org/ publications/books/abstracts/sssabookseries/m ethodsofsoilan3/961/preview

Niu X, Duiker SW (2006). Carbon sequestration potential by afforestation of marginal agricultural land in the Midwestern US. Forest Ecology and Management 223: 415-427. - doi: 10.1016/j.foreco.2005.12.044

O'Connell AM, Sankaran KV (1997). Organic matter accretion, decomposition and mineralisation. In: "Management of Soil, Nutrients and Water in Tropical Plantation Forests" (Nambiar EKS, Brown AG eds). Australian Center for International Agricultural Research (ACIAR), Canberra, ACT, Australia, pp. 443-480.

Oliet JA, Jacobs DF (2012). Restoring forests: advances in techniques and theory. New Forests 43: 535-541. - doi: 10.1007/s11056-012-9354-4

Ouimet R, Tremblay S, Périé C, Prégent G (2007). Ecosystem carbon accumulation following fallow farmland afforestation with red pine in southern Quebec. Canadian Journal of Forest Research 37: 1118-1133. - doi: 10.1139/X06-297

Okland T, Rydgen K, Okland RH, Storaunet KO, Rolstad J (2003). Variation in environmental conditions, understory species number, abundance and composition among natural and managed Picea abies forest stands. Forest Ecology and Management, 177: 17-37. - doi: 10.1016/ S0378-1127(02)00331-6

Panagopoulos T, Hatzistathis A (1995). Early growth of Pinus nigra and Robinia pseudoacacia stands: contributions to soil genesis and landscape improvement on lignite spiols in Ptolemaida. Landscape and Urban Planning 32: 1929. - doi: 10.1016/0169-2046(94)00186-7

Paul KI, Polglase PJ, Nyakuengama JG, Khanna PK (2002). Change in soil carbon following afforestation. Forest Ecology and Management 168: 241-257. - doi: 10.1016/S0378-1127(01)00740$\mathrm{X}$
Qiu L, Zhang J, Cheng X, Yin X (2010). Effects of black locust (Robinia pseudoacacia) on soil properties in the loessial gully region of the Loess Plateau, China. Plant Soil 332: 207-217. - doi: 10.1007/s11104-010-0286-5

Ratknić M, Bilibajkić S, Braunović S, Miletić Z, Dražić D (2011). Basic environmental conditions. In: "The selection of species for reforestation and amelioration in central Serbia" (Tomić Z, Rakonjac Lj, Isajev V eds). Institute of Forestry, Belgrade, Serbia, pp. 17-63.

RHOS (2011). Meterorološki godišnjak [Meteorological annual reports]. Republic Hydrometeorological Office of Serbia, Belgrade, Serbia. [in Serbian]

Rhoades CC, Eckert GE, Coleman DC (1998). Effect of pasture trees on soil nitrogen and organic matter: implications for tropical montane forest restoration. Restoration Ecology 6(3): 262-270. - doi: 10.1046/j.1526-100X.1998.00639.x Rice SK, Westerman B, Federici R (2004). Impacts of exotic, nitrogen-fixing black locust (Robinia pseudoacacia) on nitrogen-cycling in a pine-oak ecosystem. Plant Ecology 174: 97-107. doi: 10.1023/B:VEGE.0000046049.21900.5a

Richter DD, Markewitz D, Trumbore ES, Wells GC (1999). Rapid accumulation and turnover of soil carbon in re/estabilshing forest. Nature 400: 56-58. - doi: 10.1038/21867

Ristić R, Ljujić M, Despotović J, Aleksić V, Radić $B$, Nikić Z, Milčanović V, Malušević I, Radonjić J (2013). Reservoir sedimentation and hydrological effects of land use change - Case study of the experimental Dičina river watershed. Carpathian Journal of Earth and Environmental Sciences 8 (1): 91- 98.

Rowell DL (1997). Bodenkunde. Untersuchungsmethoden und ihre Anwendungen [Soil Science. Research methods and their applications]. Springer, Berlin, Germany, pp. 614. [in German]

Soljanik I (1955). Research afforestation at Grdelica gorge. Šumarstvo 12: 741-756. [in Serbian]

Soškić B, Popović Z (2002). Svojstva drveta [The Properties of Wood]. Univerzitet u Beogradu Šumarski fakultet, Belgrade, Serbia, pp. 97-108. [in Serbian]

Tanasijević D (1956). Pedološko-agrohemijske osobine i stanje erozije zemljišta Grdeličke klisure i Vranjske kotline [Pedological and agrochemical soil properties and the state of soil erosion in Grdelica gorge and Vranjska valley]. Soil Science Institute, Belgrade, Serbia, pp. 200. [in Serbian]

Tangestani MH (2006). Comparison of EPM and PSIAC models in GIS for erosion and sediment yeld assessment in a semi-arid environment: Afzar Catchment, Fars Province, Iran. Journal of Asian Sciences 27: 585-597.

Tateno R, Tokuchi N, Yamanaka N, Du S, Otsuki K, Shimamura T, Xue Z, Wang S, Hou Q (2007). Comparison of litterfall production and leaf litter decomposition an exotic black locust plantation and an indigenous oak forest near Yan'an on the Loess Plateau, China. Forest Ecology and Management 241: 84-90. - doi: 10.1016/ j.foreco.2006.12.026

Tomić Z (2004). Šumska fitocenologija [Forestry phytocenology]. Univerzitet u Beogradu Šumarski fakultet, Belgrade, Serbia, pp. 261. [in Serbian]

Tošić R, Dragićević S, Lovrić N (2012). Assessment of soil erosion and sediment yield changes using erosion potential model - case study: Republic of Srpska (BiH). Carpathian Journal of Earth and Environmental Sciences 7 (4): 147154. [online] URL: http://www.researchgate.net /profile/Slavoljub_Dragicevic/publication/23598 6040

Van Wesenbeeck BK, Van Mourik T, Duivenvoorden JF, Cleef AM (2003). Strong effects of a plantation with Pinus patula on Andean subpáramo vegetation: a case study from Colombia. Biological Conservation 114: 207-218. - doi: 10.1016/S0006-3207(03)00025-9

Velašević V, Dorović M (1998). Uticaj šumskih ekosistema na životnu sredinu [The impact of forest ecosystems to the environment]. Univerzitet u Beogradu - Šumarski fakultet, Belgrade, Serbia, pp 451. [in Serbian]

Wang DH, Madley KE (2004). Land use model for carbon conservation across a midwestern USA landscape. Landscape and urban planning 69: 451-465. - doi: 10.1016/j.landurbplan.2004.01.002 Wang G, Wu B, Zhang L, Jiang H, Xu Z (2014). Role of soil erodibility in affecting available nitrogen and phosphorus losses under simulated rainfall. Journal of Hydrology 514: 180-191. - doi: 10.1016/j.jhydrol.2014.04.028

Wenhua L (2004). Degradation and restoration of forest ecosystems in China. Forest Ecology and Management 201: 33-41. - doi: 10.1016/j.for eco.2004.06.010

Whisenant S (2005). First steps in erosion control. In: "Forest restoration in landscapes: Beyond planting trees" (Mansourian S, Vallauri D, Dudly N eds). Springer, New York, USA, pp. 350-355. - doi: 10.1007/0-387-29112-1_50 WRB (2006). World reference base for soil resources 2006 - a framework for international classification correlation and communication. IUSS International Working Group, World Soil Resources Reports 103, FAO, Rome, Italy, pp. 128.

Zhang B, Yang Y, Zepp H (2004). Effect of vegetation restoration on soil and water erosion and nutrient losses of a severely eroded clayey Plinthudult in southeastern China. Catena 57: 77-90. - doi: 10.1016/j.catena.2003.07.001

Zhang Y, Liu BY, Zhang QC, Xie Y (2003). Effect of different vegetation types on soil erosion by water. Acta Botanica Sinica 45 (10): 1204-1209.

Zheng FL (2006). Effect of vegetation changes on soil erosion on the Loess Plateau. Pedosphere 16 (4): 420-427. - doi: 10.1016/S1002-016o(06) $60071-4$

Zhou ZC, Shangguan ZP, Zhao D (2006). Modelling vegetation coverage and soil erosion in the Loess Plateau Area of China. Ecological Modelling 198: 263-268. - doi: 10.1016/j.ecolmodel.20 06.04 .019

Zorn M, Komac B (2008). Response of soil erosion to land use change with particular reference to the last 200 years (Julian Alps, Western Slovenia). Revista de geomorfologie 11: 39-47. 